\title{
TINJAUAN STRUKTUR GEDUNG B RUMAH SAKIT CIMACAN
}

\author{
Disusun Oleh : \\ Wiratna Tri Nugraha, \\ Fajar Ramdani \\ Program Studi Teknik Sipil Fakultas Teknik \\ Universitas Suryakancana
}

\begin{abstract}
ABSTRAK
Rumah Sakit Umum Daerah Cimacan adalah sarana pelayanan kesehatan yang sangat penting bagi masyarakat di sekitar rumah sakit yaitu kecamatan yang berada di wilayah utara Cianjur. Desain-desain struktur yang digunakan pada bangunan ini memiliki banyak jenis, misalkan balok menggunakan 11 jenis, kolom menggunakan 5 jenis, dan pelat lantai dengan tebal $12 \mathrm{~cm}$, pelat dak dengan tebal $10 \mathrm{~cm}$ dengan desain-desain tulangan yang terpasang. Tinjauan ini dilakukan untuk melihat bagaimana jika jenis-jenis balok, kolom, maupun pelat yang digunakan sebelumnya diganti dengan jenis-jenis yang baru.

Desain baru yang direncanakan berdasarkan hasil analisis adalah Kolom menggunakan dimensi 550 $\mathrm{mm} \times 550 \mathrm{~mm}$ dengan tulangan $16 \mathrm{D} 16 \mathrm{~mm}$, balok arah X menggunakan dimensi $300 \mathrm{~mm} \times 650 \mathrm{~mm}$ dengan tulangan pada daerah tumpuan $8 \mathrm{D} 16 \mathrm{~mm}$ dan daerah lapangan $8 \mathrm{D} 16 \mathrm{~mm}$, balok arah Y menggunakan dimensi $300 \mathrm{~mm}$ x $650 \mathrm{~mm}$ dengan tulangan pada daerah tumpuan 7 D16 mm dan daerah lapangan $5 \mathrm{D} 16 \mathrm{~mm}$, balok anak menggunakan dimensi $300 \mathrm{~mm}$ x $500 \mathrm{~mm}$ dengan tulangan pada daerah tumpuan $6 \mathrm{D} 16 \mathrm{~mm}$ dan daerah lapangan $5 \mathrm{D} 16 \mathrm{~mm}$, pelat lantai dengan tebal $12 \mathrm{~cm}$ menggunakan tulangan rangkap pada lantai 2,3,4, daerah lapangan arah x menggunakan tulangan D10 - $200 \mathrm{~mm}$, daerah tumpuan arah x menggunakan tulangan D10 - $200 \mathrm{~mm}$, daerah lapangan arah y menggunakan tulangan D10 - $100 \mathrm{~mm}$, daerah tumpuan arah y menggunakan tulangan D10 - $100 \mathrm{~mm}$ dan pelat dak tebal $10 \mathrm{~cm}$ menggunakan tulangan tulangan rangkap daerah lapangan arah $\mathrm{x}$ menggunakan tulangan D10 - $200 \mathrm{~mm}$, daerah tumpuan arah x menggunakan tulangan D10 - $200 \mathrm{~mm}$, daerah lapangan arah y menggunakan tulangan D10 - $100 \mathrm{~mm}$, daerah tumpuan arah y menggunakan tulangan D10 - $100 \mathrm{~mm}$. total biaya yang dibutuhkan untuk membangun struktu atas sebesar Rp. 2.173.867.988.90 dan waktu yang dibutuhkan untuk membangun yaitu selama 12 minggu atau 3 bulan
\end{abstract}

Kata kunci: Struktur gedung, beton bertulang, SRPMM, SAP v.15, tulangan.

\section{PENDAHULUAN}

Pembangunan gedung B RUMAH SAKIT CIMACAN di Cimacan ini adalah proyek pembangunan yang dilakukan pihak swasta yaitu pihak rumah sakit. Pembangunan GEDUNG B RUMAH SAKIT CIMACAN di Cimacan. ini berlokasi di jalan raya CiawiCianjur Kabupaten Cianjur provinsi Jawa Barat. Pembangunan gedung ini bertujuan untuk melayani kebutuhan kesehatan masyarakat. Pembangunan gedung B RUMAH SAKIT CIMACAN ini direncanakan selesai dalam waktu dua belas bulan. Untuk menahan beban yang bekerja tentunya diperlukan struktur bangunan yang kuat. Jenis struktur yang dipakai dalam proyek ini adalah struktur beton. Maka dari itu memilih proyek pembangunan GEDUNG B RUMAH SAKIT CIMACAN ini sebagai bahan untuk tugas akhir. Adapun judul yang dibuat yaitu "Tinjauan Struktur Gedung B Rumah Sakit Cimacan".Desain-desain struktur yang digunakan pada bangunan ini memiliki banyak jenis, misalkan balok menggunakan 11 jenis, kolom menggunakan 5 jenis, dan pelat lantai dengan tebal $12 \mathrm{~cm}$, pelat dak dengan tebal 10 $\mathrm{cm}$ dengan desain-desain tulangan yang terpasang. Tinjauan ini dilakukan untuk melihat bagaimana jika jenis-jenis balok, kolom,maupun pelat yang digunakan 
sebelumnya diganti dengan jenis-jenis yang baru. Tujuan dari rumusan masalah diatas yaitu 1. Meninjau kekuatan dan keamanan struktur kolo, balok, dan pelat lantai beton bertulang gedung B RUMAH SAKIT CIMACAN menggunakan bantuan SNI program SAP 2000 v. 15 3Ddan Pca Coloumn.

2. Meninjau rencana anggaran biaya dan kurva $\mathrm{S}$ yang dibutuhkan untuk struktur atas gedung B rumah sakit Cimacan.

\section{METODOLOGI PENELITIAN}

Pada umumnya bahan bangunan yang sering digunakan dalam kegiatan konstruksi adalah sebagai berikut:

1. Konstruksi kayu

2. Konstruksi beton

3. Konstruksi baja

4. Konstruksi komposit

\section{a) KOLOM}

Kolom adalah komponen struktur bangunan yang tugas utamanya menyangga beban aksial tekan vertikal dengan bagian tinggi yang tidak ditopang paling tidak tiga kali dimensi lateral terkecil (SK SNI T-15-1991-03).

Kolom adalah struktur utama yang berguna untuk meneruskan berat bangunan dan beban lain seperti beban hidup, beban angin, dan beban gempa untuk didistribusikan ke pondasi dan diteruskan ke dalam tanah. Kolom dalam struktur portal harus dibuat menerus dari lantai bawah sampai lantai atas, letak kolom berada pada titik yang sama dan tidak boleh digeser, karena hal tersebut akan menghilangkan sifat kekakuan dari struktur portal. Ukuran kolom makin ke atas dapat makin kecil, sesuai dengan beban bangunan yang diterima, karena makin ke atas bebannya makin kecil.

\section{b) BALOK}

Balok adalah bagian dari struktur portal yang dirancang untuk menahan dan mentransfer beban menuju elemen-elemen kolom penopang. Balok berfungsi sebagai pengikat kolom-kolom untuk mempertahankan bentuk dan posisinya.

Tegangan yang timbul pada balok tergantung pada besar dan distribusi beban pada penampang balok. Semakin besar dimensi balok semakin kuat kemampuannya untuk memikul beban, tetapi menambah berat sendiri balok tersebut. Variabel utama dalam mendesain balok meliputi bentang, jarak antar kolom penopang, jenis dan besar beban, jenis material, ukuran dan bentuk penampang, serta cara penggabungan atau fabrikasi. Beberapa faktor yang merupakan prinsip-prinsip desain umum dalam perencanaan balok, yaitu:

1. Kontrol kekuatan dan kekakuan.

2. Variasi besaran material.

3. Variasi bentuk balok pada seluruh panjangnya.

4. Variasi kondisi tumpuan dan kondisi batas. Balok umumnya menjadi kesatuan yang monolit dengan pelat. Pelat berlaku sebagai lapis sayap tekan yaitu sebagai komponen struktur yang bekerja pada dua arah lenturan saling tegak lurus, sedangkan balok berlaku sebagai badan.

\section{c) PELAT LANTAI}

Pelat lantai adalah struktur nbangunan yang tidak berada di atastanah secara langsung. Pelat lantai dibingkai oleh balok yang kemudian dtopang oleh kolom-kolom bangunan.

Fungsi dari pelat lantai adalah:

1. Memisahkan ruang bawah dan ruang atas.

2. Sebagai tempat berpijak penghuni di lantai atas.

3. Meredam suara dari ruang atas maupun dari ruang bawah.

4. Menambah kekakuan bangunan pada arah horizontal.

Pada SNI 03-2847-2002, pelat lantai hanya menahan beban tetap (penghuni, perabotan, berat lapis keramik, berat sendiri pelat) yang bekerja dalam waktu lama. Sedangkan untuk beban tak terduga seperti gempa, angin, dan getaran tidak diperhitungkan.

Perencanaan dan hitungan pelat lantai dari beton bertulang harus mengikuti persyaratan yang tercantum dalam pedoman SK SNI T-15-1991-03. Beberapa persyaratan tersebut antara lain:

1. Pelat lantai harus mempunyai tebal sekurang-kurangnya $12 \mathrm{~cm}$, sedang untuk pelat atap sekurang-kurangnya $7 \mathrm{~cm}$.

2. Pelat lantai menggunakan tulangan silang dengan diameter minimum $8 \mathrm{~mm}$.

3. Pada pelat lantai yang tebalnya lebih dari 25 $\mathrm{cm}$ harus dipasang tulangan rangkap atas bawah.

4. Jarak tulangan pokok yang sejajar tidak kurang dari $2,5 \mathrm{~cm}$ dan tidak lebih dari 20 $\mathrm{cm}$ atau dua kali tebal pelat.

5. Semua tulangan pelat harus terlapisi beton setebal minimum $1 \mathrm{~cm}$, untuk melindungi baja dari karat, korosi, atau kebakaran.

Dalam perencanaan pelat lantai, terdapat beberapa jenis pelat lantai yang sering digunakan, diantaranya adalah: 
1. Sistem flat slab

2. Sistem lantai grid

3. Sistem lajur balok

4. Sistem pelat dan balok

\section{d) BETON BERTULANG}

Beton bertulang merupakan gabungan logis dari dua jenis bahan: beton polos yang memiliki kekuatan tekan yang tinggi tetapi kekuatan tariknyayang rendah, dan batangbatang baja yang ditanamkan di dalam beton dapat memberikan kekuatan tarik yang diperlukan. (Wang, 1993:1).

Nilai kuat tarik beton adalah sekitar 5\%-9\% kuat tekannya. Maka dari itu perkuatan sangat diperlukan dalam struktur beton. Perkuatan yang umum adalah menggunakan tulangan baja yang jika dipadukan dengan beton sering disebut dengan beton bertulang.

Untuk kuat tekan, di Indonesia sering digunakan satuan $\mathrm{kg} / \mathrm{cm}^{2}$ dengan simbol $\mathrm{K}$ untuk benda uji kubus, dan satuan MPa dengan simbol f'c untuk benda uji silinder. Kuat tekan dari beton sangat dipengaruhi oleh beberapa faktor, yaitu:

1. Jenis dan kualitas semen.

2. Jenis agregat.

3. Perawatan, hal yang sangat penting pada pekerjaan lapangan dan pada pembuatan benda uji. Perawatan yang kurang baik dapat menimbulkan kehilangan kuat tekan sekitar $40 \%$.

4. Suhu, kecepatan pengerasan beton bertambah dengan bertambah suhu. Pada titik beku kuat tekan akan tetap rendah untuk waktu yang lama.

5. Umur, pada keadaan normal kekuatan beton bertambah dengan bertambah umur.

\section{PEMBEBANAN STRUKTUR}

Beban-beban yang diperhitungkan dalam perencanaan gedung ini besarnya ditentukan oleh Peraturan Pembebanan Indonesia Untuk Gedung (PPIUG-1989).

Beban-beban yang diperhitungkan dalam perhitungan struktur adalah sebagai berikut:

1. Beban mati sendiri (DL) dari elemen struktur yang meliputi berat balok, kolom, pelat lantai, dan tangga.

2. Beban mati dari elemen tambahan (DL) yang meliputi dinding, keramik, plesteran, plumbing, mechanical electrical, plafond dan rangka plafond, waterproofing.

3. Beban hidup (LL) yang tergantung pada fungsi bangunan, yang dalam kasus ini gedung digunakan sebagai rumah sakit.
4. Beban gempa (Q), dalam kasus ini hanya ditinjau terhadap beban gempa statik ekuivalen.

\section{e) KOMBINASI BEBAN}

Kombinasi pembebanan yang digunakan mengacu pada SNI Beton 03-2847-2002, kombinasi bebana pada perhitungan struktur gedung dapat dirangkum sebagai berikut:

1. $1,4 \mathrm{DL}$

2. $1,2 \mathrm{DL}+1,6 \mathrm{LL}$

3. $1,2 \mathrm{DL}+1 \mathrm{LL}+1 \mathrm{EX}+0,3 \mathrm{EY}$

4. 1,2 DL $+1 \mathrm{LL}-1 \mathrm{EX}-0,3 \mathrm{EY}$

5. $1,2 \mathrm{DL}+1 \mathrm{LL}+0,3 \mathrm{EX}+1 \mathrm{EY}$

6. 1,2 DL + 1 LL $-0,3 \mathrm{EX}-1 \mathrm{EY}$

7. $0,9 \mathrm{DL}+1 \mathrm{EX}+0,3 \mathrm{EY}$

8. $0,9 \mathrm{DL}-1 \mathrm{EX}-0,3 \mathrm{EY}$

9. $0,9 \mathrm{DL}+0,3 \mathrm{EX}+1 \mathrm{EY}$

10. $0,9 \mathrm{DL}-0,3 \mathrm{EX}-1 \mathrm{EY}$

Dimana:

$\begin{array}{lll}- & \text { DL } & \text { : Beban mati } \\ \text { - } & \text { LL } & \text { : Beban hidup } \\ \text { - } & \text { E } & \text { : Beban gempa }\end{array}$

Tanda \pm menyatakan arah beban yang bolakbalik. Beban gempa (E) dianggap bekerja 100 $\%$ pada arah sumbu utama bersamaan dengan $30 \%$ pada arah tegak lurus sumbu utama.

\section{f) PERATURAN-PERATURAN}

Perhitungan konstruksi gedung ini memperhatikan ketentuan-ketentuan yang berlaku yang terdapat pada buku-buku pedoman antara lain:

1. Tata Cara Perhitungan Struktur Beton Untuk Bangunan Gedung (SNI 03-28472002)

2. Peraturan Pembebanan Indonesia Untuk Gedung dan Bangunan Lain (SNI 17271989).

3. Standar Perencanaan Ketahanan Gempa Untuk Struktur Bangunan Gedung (SNI03-1726-2002).

4. Tata Cara Perencanaan Struktur Baja Untuk Bangunan Gedung (SNI 03-1729-2002).

\section{g) SAP 2000 v.15 3D}

SAP 2000 merupakan sebuah program yang dikembangkan oleh perusahaan Computer \& Structure, Inc. Program SAP ini memiliki kelebihan dalam perancangan struktur baja dan beton agar dimensi yang digunakan bisa optimal dan ekonomis.

Program ini dapat membantu dalam perhitungan analisis struktur dan desain. Program ini digunakan untuk merancang, menganalisa, dan menampilkan geometri 
struktur, properti, dan hasil analisis. Hasil analisis ini berupa nilai-nilai yang selanjutnya digunakan untuk perhitungan-perhitungan yang mempengaruhi struktrur, seperti tulangan pokok, tulangan geser, dll.

\section{h) PCA COLOUMN}

Pca Coloumn dapat digunakan untuk mendesain atau mengecek struktur kolom. Setelah melakukan analisa struktur secara manual maupun menggunakan software yang dalam hal ini adalah SAP 2000, dan diperoleh gaya-gaya yang bekerja pada kolom, maka langkah selanjutnya adalah melakukan desain tulangan kolom.

Data-data yang diperlukan dalam analisis kolom menggunakan program Pca Coloumn ini adalah momen lentur dan gaya aksial tekan yang dipikul oleh kolom. Dari kedua data ini, Pca Coloumn akan menampilkan diagram interaksi, dimana diagram ini adalah diagram yang menunjukan hubungan momen lentur dan gaya aksial tekan yang dapat dipikul oleh elemen kolom pada kondisi batas. Jika semua beban masih berada di dalam garis diagram, maka kolom tersebut mampu menahan beban tersebut (aman), jika beban berada di luar garis diagram dapat disimpulkan bahwa kolom tidak mampu menahan beban. Jika hal ini terjadi, alternatif yang bisa dilakukan diantaranya adalah menaikan mutu beton, menambah jumlah tulangan, dan memperbesar ukuran kolom.

\section{ANALISA PEMBEBANAN}

Beban yang bekerja pada struktur diambil dari berat sendiri struktur, beban mati tambahan dari komponen pendukung, dan beban hidup yang telah ditentukan pada tabel 1 dan tabel 2, Tata Cara Perencanaan Pembebanan untuk Rumah dan Gedung, SNI 03-1727-1989.

1. Beban mati pada pelat lantai
a. Finishing $(2,5 \mathrm{~cm})$
$53 \mathrm{Kg} / \mathrm{m}^{2}$
b. Pasangan keramik
$24 \mathrm{Kg} / \mathrm{m}^{2}$
c. ME
$25 \mathrm{Kg} / \mathrm{m}^{2}$
d. Plafond dan rangka
$18 \mathrm{Kg} / \mathrm{m}^{2}$
e. Sanitasi/plumbing
$30 \mathrm{Kg} / \mathrm{m}^{2}$
f. Partisi
$100 \mathrm{Kg} / \mathrm{m}^{2}$

2. Berat mati pada pelat atap
a. Waterproofing
b. ME
$105 \mathrm{Kg} / \mathrm{m}^{2}$
$25 \mathrm{Kg} / \mathrm{m}^{2}$
c. Plafond dan rangka
$18 \mathrm{Kg} / \mathrm{m}^{2}$
d. Sanitasi/plumbing
$30 \mathrm{Kg} / \mathrm{m}^{2}$

3. Beban tambahan lainnya, yaitu dinding. Beban ini tergantung pada tinggi dinding dan panjang balok yang menahan dinding tersebut.

Beban hidup merupakan beban yang bukan berasal dari berat komponen-komponen bangunan, atau secara garis besar yaitu beban yang berasal dari orang atau benda yang tidak tetap dalam bangunan.

1. Beban hidup pada pelat lantai sebesar 250 $\mathrm{Kg} / \mathrm{m}^{2}$

2. Beban hidup pada pelat atap sebesar 100 $\mathrm{Kg} / \mathrm{m}^{2}$

Beban gempa menggunakan perhitungan sistem rangka pemikul momen menengah (SRPMM), dikarenakan bangunan terletak di wilayah gempa zona 4 dan beban gempa yang direncanakan adalah beban gempa statik ekivalen.

\begin{tabular}{|r|r|r|}
\hline \multirow{2}{*}{ Fix=Fiy (Kg) } & Untuk Tiap Portal $x$ & \multicolumn{1}{|c|}{ Untuk Tiap Portal y } \\
\cline { 2 - 3 } & $1 / 5 . F i(\mathrm{Kg})$ & $1 / 4 . \mathrm{Fi}(\mathrm{Kg})$ \\
\hline 25275,85885 & 5055,17177 & 6318,96471 \\
\hline 40945,59862 & 8189,11972 & 10236,39965 \\
\hline 66678,36725 & 13335,67345 & 16669,59181 \\
\hline 80220,80909 & 16044,16182 & 20055,20227 \\
\hline 89409,71852 & 17881,94370 & 22352,42963 \\
\hline 109392,03598 & 21878,40720 & 27348,00899 \\
\hline 91405,05131 & 18281,01026 & 22851,26283 \\
\hline
\end{tabular}

\section{a) DIMENSIONING STRUKTUR}

Dimensi-dimensi pada struktur yang digunakan adalah:

1. Pelat, dimensi pelat yang digunakan yaitu tebal $12 \mathrm{~cm}$ dan atap $10 \mathrm{~cm}$.

2. Balok, dimensi balok yang akan dianalisa yaitu balok dengan gaya dalam terbesar dari tiap lantai, yaitu:

a. Balok $650 \mathrm{~mm} \times 300 \mathrm{~mm}$

b. Balok $500 \mathrm{~mm} \times 300 \mathrm{~mm}$

Kolom, dimensi kolom yang akan dianalisa adalah kolom dengan gaya dalam terbesar, yaitu kolom $550 \mathrm{~mm}$ x $550 \mathrm{~mm}$.

\section{b) PENULANGAN PELAT}

Tulangan pelat lantai yang digunakan adalah baja tulangan ulir (deform) dengan mutu fy = 400 Mpa untuk $\mathrm{D} \geq 10 \mathrm{~mm}$ dan mutu beton $\mathrm{fc}$ $=25 \mathrm{Mpa}$ dengan selimut beton $25 \mathrm{~mm}$. Tipe pelat yang digunakan pada tiap lantai merupakan pelat yang dijepit pada keempat sisinya, dan menahan beban kerja yang ada di atasnya.

Perhitungan menggunakan sistem pelat dua arah yaitu pelat dengan perbandingan panjang dan lebar kurang dari sama dengan 2,5 (Ly/Lx $\leq 2,5$ ), tulangan dipasang pada dua arah yang saling tegak lurus.

Pelat lantai dan dak

Pelat yang dianalisa merupakan pelat dengan perbandingan panjang dan lebar terbesar, dan 
mewakili seluruh pelat lantai yaitu dengan Lx $=3 \mathrm{~m}$ dan $\mathrm{Ly}=7.073 \mathrm{~m}$.

Beban-beban yang diterima oleh pelat yaitu:
1. Beban mati
$=438 \mathrm{~kg} / \mathrm{m}^{2}$
2. Beban hidup
$=250 \mathrm{~kg} / \mathrm{m}^{2}$
3. Beban terfaktor
$=925,6 \mathrm{~kg} / \mathrm{m}^{2}$

Menghitung nilai momen yang bekerja pada pelat

Mlx $(+)=0,001 \cdot q u \cdot \operatorname{Lx}^{2} \cdot \mathrm{x}$

Mly $(+)=0,001 \cdot q u \cdot$ Ly $^{2} \cdot x$

Mtx (-) $=0,001 \cdot q u \cdot$ Lx $^{2} \cdot x$

Mty $(-)=0,001 \cdot q u \cdot$ Ly $^{2} \cdot x$

Menghitung jarak tulangan yang digunakan pada pelat:

$$
\begin{aligned}
& >\mathrm{K}=\frac{M u}{\emptyset b d^{2}}=\frac{506,999 \cdot 10^{4}}{0,8 \cdot 1000 \cdot 90^{2}}=0,782 \mathrm{Mpa} \\
& \rho=0.85 \times \frac{f c}{f y} \times\left[1-\sqrt{1-\frac{2 . K}{0,85 . f c}}\right] \\
& =0.85 \times \frac{25}{400} \times\left[1-\sqrt{1-\frac{2.0,99}{0,85.25}}\right]=0,0025 \\
& \rho \min =\frac{1,4}{f y}=\frac{1,4}{400}=0,0035 \\
& \rho \mathrm{b}=0,85 \cdot \beta_{1} \cdot \frac{f c}{f y}\left[\frac{600}{f y+600}\right] \\
& =0,85 \cdot 0,85 \cdot \frac{25}{400}\left[\frac{600}{400+600}\right]=0,0271 \\
& \rho \max =0,75 . \rho b=0,0203 \\
& \text { As perlu }=\rho \cdot b \cdot d=315 \mathrm{~mm}^{2} \\
& \text { As } \max =\rho \max \cdot b \cdot d=1827 \mathrm{~mm}^{2} \\
& \text { s perlu }=\frac{1 / 4 \pi D^{2} b}{A s \text { perlu }}=\frac{1 / 4 \pi 10^{2} .1000}{315} \\
& =249,206 \mathrm{~mm} \\
& \mathrm{~s} \max =2 . h=2.120=240 \mathrm{~mm}
\end{aligned}
$$

Jarak tulangan (s) yang dipakai yaitu $200 \mathrm{~mm}$.

$$
\begin{aligned}
\text { As } & =\frac{1 / 4 \pi D^{2} b}{s}=\frac{\frac{1}{4} \pi 10^{2} .1000}{200} \\
& =392,5 \mathrm{~mm}^{2}>\text { As perlu }\left(315 \mathrm{~mm}^{2}\right)
\end{aligned}
$$

$$
\begin{aligned}
& \text { Kontrol momen pada pelat } \\
& \begin{aligned}
\mathrm{Mlx} & =506,999 \mathrm{Kgm} \\
\varnothing \mathrm{Mn} & =\varnothing \mathrm{x} \text { As terpasang } \mathrm{x} \text { fy } \mathrm{x} \mathrm{jd} \\
& =10,4562 \mathrm{kNm}=1045,62 \mathrm{Kgm}
\end{aligned} \\
& \varnothing \mathrm{Mn}(1045,62)>\mathrm{Mlx}(506,999)
\end{aligned}
$$

\section{Kontrol lendutan}

$\mathrm{Ec}=23500 \mathrm{Mpa}$

$\mathrm{Es}=200000 \mathrm{Mpa}$

$\mathrm{qD}+\mathrm{qL}=438+250=6,88 \mathrm{~N} / \mathrm{mm}$

$\mathrm{Lx}=3000 \mathrm{~mm}$

Lendutan ijin $=\mathrm{Lx} / 240=12,5 \mathrm{~mm}$

$\mathrm{Ig}=1 / 12 \cdot \mathrm{b} \cdot \mathrm{h}^{3}=144 \cdot 10^{6} \mathrm{~mm}^{4}$

$\mathrm{fr}=0,7 \sqrt{f c}=3,5 \mathrm{Mpa}$

$\mathrm{n}=\mathrm{Es} / \mathrm{Ec}=8,511$

$\mathrm{c}=\mathrm{n} \cdot \frac{A s}{b}=3,341 \mathrm{~mm}$

Icr $=\left(1 / 3 \cdot b \cdot c^{3}\right)+\left(\right.$ n.As. $\left.(d-c)^{2}\right)$
$=19643617,65 \mathrm{~mm}^{4}$

$\mathrm{yt}=\mathrm{h} / 2=60 \mathrm{~mm}$

Mcr $=\frac{(\text { fr.Ig })}{y t}=84.10^{5} \mathrm{Mpa}$

$\mathrm{Ma}=1 / 8 \cdot \mathrm{q} \cdot \mathrm{Lx}^{2}=1 / 8 \cdot 6,88 \cdot 3000^{2}$

$=7740000 \mathrm{Nmm}$

$\mathrm{Ie}=\left(\frac{M c r}{M a}\right)^{3} \times I g+\left(1-\left(\frac{M c r}{M a}\right)^{3}\right) \times I c r$

$=150813280,9 \mathrm{~mm}^{4}$

Lendutan seketika akibat beban mati dan beban hidup

$\delta e=\left(\frac{5}{384}\right) \cdot \mathrm{q} \cdot \mathrm{Lx}^{4} /($ Ec.Ie $)=2,047 \mathrm{~mm}$

$\rho=\frac{A s}{b . d}=\frac{392,5}{1000.90}=0,00436$

$\mathrm{T}=2$

$$
\begin{aligned}
& \square \square \square \square \frac{T}{1+50 \rho} \square \square \frac{2}{1+50.0,00436}=1,642 \\
& \begin{aligned}
\delta g=\square & \square \frac{5}{384} \frac{q L x^{4}}{E c . I e}=3,396 \mathrm{~mm}
\end{aligned} \\
& \begin{aligned}
\text { Stotal } & =\delta e+\delta g=2,032+3,396 \\
& =5,464 \mathrm{~mm}<12,5 \mathrm{~mm} \text { (aman) }
\end{aligned}
\end{aligned}
$$

Dengan menggunakan metode yang sama, dapat dihitung pula momen-momen yang bekerja pada pelat yang lain.

\section{c) PELAT LANTAI DAK}

Pelat yang dianalisa merupakan pelat dengan perbandingan panjang dan lebar terbesar, dan mewakili seluruh pelat atap yaitu dengan $\mathrm{Lx}=$ $3 \mathrm{~m}$ dan Ly $=7.073 \mathrm{~m}$. Jika dilihat dari segi ukuran, pelat ini tidak masuk dalam kategori pelat dua arah, tapi dalam pelaksanaan di lapangan dan perhitungan pelat dilakukan secara dua arah.

Beban-beban yang diterima oleh pelat yaitu:
1. Beban mati
$=466 \mathrm{~kg} / \mathrm{m}^{2}$
2. Beban hidup
$=100 \mathrm{~kg} / \mathrm{m}^{2}$
3. Beban terfaktor$$
=719,2 \mathrm{~kg} / \mathrm{m}^{2}
$$

Sama seperti sebelumnya perhitungan momenmomen yang diterima oleh pelat, jarak tulangan, kontrol momen, dan kontrol lendutan yang dilakukan rumus-rumus yang digunakan tidak berbeda dengan pelat lantai sebelumnya.

\section{d) PENULANGAN BALOK}

Balok yang dianalisa merupakan balok dengan nilai gaya dalam terbesar dari setiap lantai. Tulangan yang digunakan adalah baja ulir (deform) dengan mutu fy $=400 \mathrm{Mpa}$ untuk D $\geq$ $10 \mathrm{~mm}$ dan beton dengan mutu $\mathrm{fc}=25 \mathrm{Mpa}$.

Balok induk arah $\mathrm{X}$ dengan data sebagai berikut:

Dimensi balok $\quad 0,3 \mathrm{~m} \mathrm{x} 0,65 \mathrm{~m}$

Tulangan pokok D16 mm

Tulangan sengkang D10 mm

Selimut beton $\quad 50 \mathrm{~mm}$ 
Momen rencana akibat beban terfaktor adalah:

$\begin{array}{lc}\text { Mut }_{1} & : 200,7013 \mathrm{kNm} \\ \text { Mut }_{2} & : 211,5044 \mathrm{kNm} \\ \text { Mul } & : 201 ., 6755 \mathrm{kNm} \\ \mathrm{Vu} & : 191,439 \mathrm{kN} \\ \mathrm{d}_{\mathrm{ix}}=\mathrm{h}-\mathrm{sb}-\mathrm{s}-1 / 2 \mathrm{D}=582 \mathrm{~mm} \\ \mathrm{jd}_{\mathrm{ix}}=0,875 \times \mathrm{d}_{\mathrm{ix}}=509,25 \mathrm{~mm}\end{array}$

Luas tulangan yang diperlukan pada tumpuan As perlu $=\frac{M u}{\text { Q.fy.jd }}=1597.40493 \mathrm{~mm}^{2}$

Tulangan yang digunakan, yaitu: $\mathrm{n}=\frac{\text { As perlu }}{\text { Luas tulangan }}=7.94164 \approx 8$ Buah

tulangan 8 D $16 \mathrm{~mm}\left(\mathrm{~A}=1609.143 \mathrm{~mm}^{2}\right)$ Luas tulangan yang diperlukan pada lapangan As perlu $=\frac{M u}{\text { a.fy.jd }}=1523.1713 \mathrm{~mm}^{2}$

Tulangan yang digunakan, yaitu: $\mathrm{n}=\frac{\text { As perlu }}{\text { Luas tulangan }}=7.57258 \approx 8$ buah

Digunakan tulangan 8 D 16 mm $(A=1609.143$ $\mathrm{mm}^{2}$ )

Nilai a dan cek kondisi tulangan tumpuan $\mathrm{a}=\frac{A s . f y}{0,85 . f c . b}=100,229 \mathrm{~mm}$

$\mathrm{Jd}$ baru $=\mathrm{d}-\frac{a}{2}=531.885 \mathrm{~mm}$

As baru $=\frac{M u}{\text { o.fy.jd }}=1529.424 \mathrm{~mm}^{2}$

Tulangan yang digunakan, yaitu: $\mathrm{n}=\frac{\text { As perlu }}{\text { Luas tulangan }}=7.603 \approx 8$ Buah

Digunakan tulangan 8 D16 mm $(\mathrm{A}=1609.143$ $\mathrm{mm}^{2}$ )

Nilai a dan cek kondisi tulangan lapangan $\mathrm{a}=\frac{\text { As.fy }}{\text { 0,85.fc.b}}=95.572 \mathrm{~mm}$

$\mathrm{Jd}$ baru $=\mathrm{d}-\frac{a}{2}=534.214 \mathrm{~mm}$

As baru $=\frac{M u}{\text { Q.fy.jd }}=1451.992 \mathrm{~mm}^{2}$

Tulangan yang digunakan, yaitu: $\mathrm{n}=\frac{\text { As perlu }}{\text { Luas tulangan }}=7.219 \approx 8$ Buah Digunakan tulangan 8 D16 mm $(\mathrm{A}=1609.143$ $\mathrm{mm}^{2}$ )

Kontrol kuat momen tulangan tumpuan $\varnothing$ Momen rencana $\geq$ Momen ultimate $\varnothing . \mathrm{Mn}=\varnothing \times$ As perlu baru $\mathrm{x}$ fy $\mathrm{x} \mathrm{jd}$ baru $=0,8 \times 1529,424 \times 400 \times 531,885$ $=260,313 \mathrm{kNm}>\mathrm{Mu}=211,504 \mathrm{kNm}$ Jadi tulangan yang digunakan 8 D16 mm, di bagian atas balok $5 \mathrm{D} 16 \mathrm{~mm}$, dan di bagian bawah balok 3 D16 mm.
$\mathrm{Mu}_{1}=141,003 \mathrm{kNm}$

$\mathrm{Mu}_{2}=70,502 \mathrm{kNm}$

As terpasang atas $=\mathrm{n} \times$ Luas tulangan $=5.201 .143=1005,715 \mathrm{~mm}$

As terpasang bawah $=\mathrm{n} \times$ Luas tulangan $=3.201 .143=603,429 \mathrm{~mm}$

Dari data mengenai tulangan yang digunakan, diperlukan cek kuat tulangan yang digunakan:

$\varnothing . \mathrm{Mn}_{1}=\varnothing \times$ As terpasang $\mathrm{x}$ fy $\mathrm{x} \mathrm{jd}$ baru $=0,8.1005,715.400 .531 .885$ $=171,176 \mathrm{kNm}$

$\varnothing . \mathrm{Mn}_{2}=\varnothing$. As terpasang $\mathrm{x}$ fy $\mathrm{x} \mathrm{jd}$ baru $=0,8.603,429.400 .531 .885$ $=102,706 \mathrm{kNm}$

$\mathrm{Mr}=\varnothing \cdot \mathrm{Mn}_{1}+\varnothing \cdot \mathrm{Mn}_{2}$

$=171,176+102,706$

$=273,882 \mathrm{kNm}$

$\mathrm{Mr}>\mathrm{Mu}_{1}+\mathrm{Mu}_{2}$

$273,882 \mathrm{kNm}>211,5044 \mathrm{kNm}$ (aman)

Kontrol kuat momen tulangan lapangan $\varnothing$ Momen rencana $\geq$ Momen ultimate Balok induk arah " $\mathrm{X}$ " tulangan lapangan Ø.Mn $=\varnothing \times$ As perlu baru $\mathrm{x}$ fy $\mathrm{x}$ jd baru $=0,8 \times 1451,99 \times 400 \times 534,214$ $=248,216 \mathrm{kNm}>\mathrm{Mu}=201,675 \mathrm{kNm}$

Jadi tulangan yang digunakan $8 \mathrm{D} 16 \mathrm{~mm}$, di bagian atas balok $3 \mathrm{D} 16 \mathrm{~mm}$, dan di bagian bawah balok 5 D16 $\mathrm{mm}$.

$\mathrm{Mu}_{1}=67,2252 \mathrm{kNm}$

$\mathrm{Mu}_{2}=134,451 \mathrm{kNm}$

As terpasang atas $=\mathrm{n} \times$ Luas tulangan $=3.201 .143=603,429 \mathrm{~mm}$

As terpasang bawah $=\mathrm{n} \times$ Luas tulangan $=5.201 .143=1005,715 \mathrm{~mm}$

Dari data mengenai tulangan yang digunakan, diperlukan cek kuat tulangan yang digunakan:

$\varnothing . \mathrm{Mn}_{1}=\varnothing \times$ As terpasang $\mathrm{x}$ fy $\mathrm{x}$ jd baru $=0,8.603,429.400 .534,214$ $=103,156 \mathrm{kNm}$

$\varnothing . \mathrm{Mn}_{2}=\varnothing$. As terpasang $\mathrm{x}$ fy $\mathrm{x} \mathrm{jd}$ baru $=0,8 \cdot 1005,715.400 .534,214$ $=171,926 \mathrm{kNm}$

$\mathrm{Mr}=\varnothing \cdot \mathrm{Mn}_{1}+\varnothing \cdot \mathrm{Mn}_{2}$

$=103,156+171,926$

$=275,082 \mathrm{kNm}$

$\mathrm{Mr}>\mathrm{Mu}_{1}+\mathrm{Mu}_{2}$

$275,082 \mathrm{kNm}>201,675 \mathrm{kNm}$ (aman)

Mengecek kondisi tulangan

$\rho$ terpasang $\leq \rho \max$

$\rho \mathrm{b}=\frac{0,85 . f c . \beta 1}{f y} \cdot \frac{600}{(600+f y)}=0.02709$

$\rho \max =0,75 \times \rho b=0.02032$ 
Cek tulangan max

Balok induk arah " $\mathrm{X}$ "

$\rho=\frac{\text { As perlu }}{b \times d}=\frac{1451,992}{300 \times 582}$

$=0.00832>\rho \max =0,02032$

Karena dengan tulangan sebanyak 8 D16 mm, nilai $\rho$ kurang dari $\rho$ max maka tulangan sebanyak 8 D16 mm aman.

Balok induk arah $\mathrm{Y}$ dengan data sebagai berikut:

Dimensi balok $\quad 0,3 \mathrm{~m} \times 0,65 \mathrm{~m}$

Tulangan pokok D16 mm

Tulangan sengkang D10 mm

Selimut beton $\quad 50 \mathrm{~mm}$

Momen rencana akibat beban terfaktor adalah:

Mut $_{1} \quad: 183,2202 \mathrm{kNm}$

Mut $_{2} \quad: 173,9964 \mathrm{kNm}$

Mul $\quad: 126,4047 \mathrm{kNm}$

$\mathrm{Vu} \quad: 134,348 \mathrm{kN}$

$\mathrm{d}_{\mathrm{iy}}=\mathrm{h}-\mathrm{sb}-\mathrm{s}-1 / 2 \mathrm{D}=582 \mathrm{~mm}$

$\mathrm{jd}_{\mathrm{iy}} \quad=0,875 \mathrm{xd}_{\mathrm{ix}}=509,25 \mathrm{~mm}$

Luas tulangan yang diperlukan pada tumpuan

As perlu $=\frac{M u}{\text { Q.fy.jd }}=1383.786 \mathrm{~mm}^{2}$

Tulangan yang digunakan, yaitu:

$\mathrm{n}=\frac{\text { As perlu }}{\text { Luas tulangan }}=6.87962 \approx 7$ Buah

Digunakan tulangan 7 D $16 \mathrm{~mm}(\mathrm{~A}=1408$ $\mathrm{mm}^{2}$ )

Luas tulangan yang diperlukan pada lapangan As perlu $=\frac{M u}{\text { Q.fy.jd }}=954.682 \mathrm{~mm}^{2}$

Tulangan yang digunakan, yaitu: $\mathrm{n}=\frac{\text { As perlu }}{\text { Luas tulangan }}=4.746 \approx 5$ buah

Digunakan tulangan $5 \mathrm{D} 16 \mathrm{~mm}$ (A = $1005.7143 \mathrm{~mm}^{2}$ )

Nilai a dan cek kondisi tulangan tumpuan $\mathrm{a}=\frac{A s . f y}{0,85 . f c . b}=86.82580 \mathrm{~mm}$

$\mathrm{Jd}$ baru $=\mathrm{d}-\frac{a}{2}=538.587 \mathrm{~mm}$

As baru $=\frac{M u}{\text { Q.fy.jd }}=1308.410 \mathrm{~mm}^{2}$

Tulangan yang digunakan, yaitu:

$\mathrm{n}=\frac{\text { As perlu }}{\text { Luas tulangan }}=6.50488 \approx 7$ Buah

Digunakan tulangan $7 \mathrm{D} 16 \mathrm{~mm}(\mathrm{~A}=1408$ $\mathrm{mm}^{2}$ )

Nilai a dan cek kondisi tulangan lapangan

$\mathrm{a}=\frac{\text { As.fy }}{0,85 . f \text { c.b }}=59,902 \mathrm{~mm}$

$\mathrm{Jd}$ baru $=\mathrm{d}-\frac{a}{2}=552,049 \mathrm{~mm}$

As baru $=\frac{M u}{\text { o.fy.jd }}=880,667 \mathrm{~mm}^{2}$

Tulangan yang digunakan, yaitu: $\mathrm{n}=\frac{\text { As perlu }}{\text { Luas tulangan }}=4.378 \approx 5$ Buah

Digunakan tulangan $5 \mathrm{D} 16 \mathrm{~mm}$ (A = $1005.71429 \mathrm{~mm}^{2}$ )

Kontrol kuat momen tulangan tumpuan

$\varnothing$ Momen rencana $\geq$ Momen ultimate

$\varnothing . \mathrm{Mn}=\varnothing \times$ As perlu baru $\mathrm{x}$ fy $\mathrm{x} \mathrm{jd}$ baru $=0,8 \times 1308,4106 \times 400 \times 538,587$

$=225,501 \mathrm{kNm}>\mathrm{Mu}=183,220 \mathrm{kNm}$

Jadi tulangan yang digunakan $8 \mathrm{D} 16 \mathrm{~mm}$, di bagian atas balok $4 \mathrm{D} 16 \mathrm{~mm}$, dan di bagian bawah balok 3 D16 $\mathrm{mm}$.

$\mathrm{Mu}_{1}=122,1468 \mathrm{kNm}$

$\mathrm{Mu}_{2}=61,0734 \mathrm{kNm}$

As terpasang atas $=\mathrm{n} \times$ Luas tulangan $=4.201 .143=840,572 \mathrm{~mm}$

As terpasang bawah $=\mathrm{n} \times$ Luas tulangan $=3.201 .143=603,429 \mathrm{~mm}$

Dari data mengenai tulangan yang digunakan, diperlukan cek kuat tulangan yang digunakan:

$\varnothing . \mathrm{Mn}_{1}=\varnothing \times$ As terpasang $\mathrm{x}$ fy $\mathrm{x} \mathrm{jd}$ baru $=0,8.840,572.400 .538 .587$ $=144,871 \mathrm{kNm}$

$\varnothing . \mathrm{Mn}_{2}=\varnothing$. As terpasang $\mathrm{x}$ fy $\mathrm{x}$ jd baru $=0,8.603,429.400 .538 .587$ $=103,999 \mathrm{kNm}$

$\mathrm{Mr}=\varnothing \cdot \mathrm{Mn}_{1}+\varnothing \cdot \mathrm{Mn}_{2}$

$=144,871+103,999$

$=248,87 \mathrm{kNm}$

$\mathrm{Mr}>\mathrm{Mu}_{1}+\mathrm{Mu}_{2}$

$248,87 \mathrm{kNm}>183,2202 \mathrm{kNm}$ (aman)

Kontrol kuat momen tulangan lapangan

$\varnothing$ Momen rencana $\geq$ Momen ultimate

$\varnothing . \mathrm{Mn}=\varnothing \times$ As perlu baru $\mathrm{x}$ fy $\mathrm{x} \mathrm{jd}$ baru

$=0,8 \times 880,667 \times 400 \times 552,049$

$=155,575 \mathrm{kNm}>\mathrm{Mu}=126,404 \mathrm{kNm}$

Jadi tulangan yang digunakan 5 D16 mm, di bagian atas balok $2 \mathrm{D} 16 \mathrm{~mm}$, dan di bagian bawah balok $3 \mathrm{D} 16 \mathrm{~mm}$.

$\mathrm{Mu}_{1}=42,1349 \mathrm{kNm}$

$\mathrm{Mu}_{2}=84,2698 \mathrm{kNm}$

As terpasang atas $=\mathrm{n} \times$ Luas tulangan $=2.201 .143=402,286 \mathrm{~mm}$

As terpasang bawah $=\mathrm{n} \times$ Luas tulangan $=3.201 .143=603,429 \mathrm{~mm}$

Dari data mengenai tulangan yang digunakan, diperlukan cek kuat tulangan yang digunakan:

$\varnothing . \mathrm{Mn}_{1}=\varnothing \times$ As terpasang $\mathrm{x}$ fy $\mathrm{x}$ jd baru $=0,8.402,286.400 .552,049$

$=71,067 \mathrm{kNm}$

$\varnothing . \mathrm{Mn}_{2}=\varnothing$. As terpasang $\mathrm{x}$ fy $\mathrm{x} \mathrm{jd}$ baru 


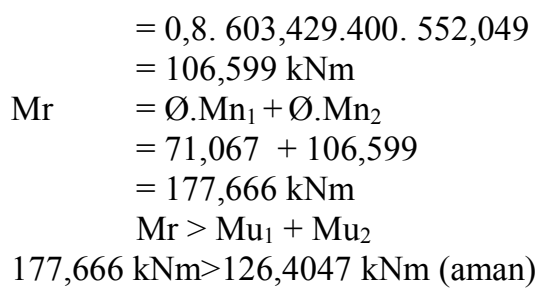

Mengecek kondisi tulangan

$\rho$ terpasang $\leq \rho \max$

$\rho \mathrm{b}=\frac{0,85 . f c . \beta 1}{f y} \cdot \frac{600}{(600+f y)}=0.02709$

$\rho \max =0,75 \times \rho b=0.02032$

Cek tulangan max

Balok induk arah "Y"

$\rho=\frac{\text { As perlu }}{b \times d}=\frac{880,667}{300 \times 582}$

$=0.00504>\rho \max =0,02032$

Karena dengan tulangan sebanyak 7 D16 mm, nilai $\rho$ kurang dari $\rho \max$ maka tulangan sebanyak 7 D16 mm aman.

Balok anak dengan data sebagai berikut:

$\begin{array}{ll}\text { Dimensi balok } & 0,3 \mathrm{~m} \mathrm{x} \mathrm{0,65} \mathrm{m} \\ \text { Tulangan pokok } & \text { D16 mm } \\ \text { Tulangan sengkang } & \text { D10 mm } \\ \text { Selimut beton } & 50 \mathrm{~mm}\end{array}$

Momen rencana akibat beban terfaktor adalah:

Mut $_{2} \quad: 109,2092 \mathrm{kNm}$

Mul : $95.6961 \mathrm{kNm}$

$\mathrm{Vu} \quad: 102,902 \mathrm{kN}$

$\mathrm{d}_{\mathrm{ia}}=\mathrm{h}-\mathrm{sb}-\mathrm{s}-1 / 2 \mathrm{D}=432 \mathrm{~mm}$

$\mathrm{jd}_{\mathrm{ia}} \quad=0,875 \times \mathrm{d}_{\mathrm{ia}}=378 \mathrm{~mm}$

Luas tulangan yang diperlukan pada tumpuan

As perlu $=\frac{M u}{\text { Q.fy.jd }}=1200.469 \mathrm{~mm}^{2}$

Tulangan yang digunakan, yaitu:

$\mathrm{n}=\frac{\text { As perlu }}{\text { Luas tulangan }}=5.96824 \approx 6$ Buah

Digunakan tulangan 6 D $16 \mathrm{~mm}(\mathrm{~A}=1206.857$ $\mathrm{mm}^{2}$ )

Luas tulangan yang diperlukan pada lapangan

As perlu $=\frac{M u}{\text { e.fy.jd }}=973.708 \mathrm{~mm}^{2}$

Tulangan yang digunakan, yaitu:

$\mathrm{n}=\frac{\text { As perlu }}{\text { Luas tulangan }}=4.84088 \approx 5$ buah

Digunakan tulangan 5 D $16 \mathrm{~mm}(\mathrm{~A}=$ $1005.7143 \mathrm{~mm}^{2}$ )

Nilai a dan cek kondisi tulangan tumpuan $\mathrm{a}=\frac{A s \cdot f y}{0,85 . f c . b}=75.323 \mathrm{~mm}$
$\mathrm{Jd}$ baru $=\mathrm{d}-\frac{a}{2}=394.33823 \mathrm{~mm}$

As baru $=\frac{M u}{\text { Q.fy.jd }}=1150.73122 \mathrm{~mm}^{2}$

Tulangan yang digunakan, yaitu:

$\mathrm{n}=\frac{\text { As perlu }}{\text { Luas tulangan }}=5.721 \approx 6$ Buah

Digunakan tulangan 6 D16 mm $(\mathrm{A}=1206.857$ $\mathrm{mm}^{2}$ )

Nilai a dan cek kondisi tulangan lapangan

$\mathrm{a}=\frac{A s . f y}{0,85 . f c . b}=61.095 \mathrm{~mm}$

$\mathrm{Jd}$ baru $=\mathrm{d}-\frac{a}{2}=401.452 \mathrm{~mm}$

As baru $=\frac{M u}{\text { Q.fy.jd }}=916.826 \mathrm{~mm}^{2}$

Tulangan yang digunakan, yaitu:

$\mathrm{n}=\frac{\text { As perlu }}{\text { Luas tulangan }}=4.5581 \approx 5$ Buah

Digunakan tulangan $5 \mathrm{D} 16 \mathrm{~mm}(\mathrm{~A}=$ $1005.71429 \mathrm{~mm}^{2}$ )

Kontrol kuat momen tulangan tumpuan

$\varnothing$ Momen rencana $\geq$ Momen ultimate

$\varnothing . \mathrm{Mn}=\varnothing \times$ As perlu baru $\mathrm{x}$ fy $\mathrm{x} \mathrm{jd}$ baru $=0,8 \times 1150,731 \times 400 \times 349,338$

$=145,208 \mathrm{kNm}>\mathrm{Mu}=117,982 \mathrm{kNm}$

Jadi tulangan yang digunakan $6 \mathrm{D} 16 \mathrm{~mm}$, di bagian atas balok $4 \mathrm{D} 16 \mathrm{~mm}$, dan di bagian bawah balok 2 D16 $\mathrm{mm}$.

$\mathrm{Mu}_{1}=78,6548 \mathrm{kNm}$

$\mathrm{Mu}_{2}=39,3274 \mathrm{kNm}$

As terpasang atas $=\mathrm{n} \times$ Luas tulangan $=4.201 .143=840,572 \mathrm{~mm}$

As terpasang bawah $=\mathrm{n} \times$ Luas tulangan $=2.201 .143=402,286 \mathrm{~mm}$

Dari data mengenai tulangan yang digunakan, diperlukan cek kuat tulangan yang digunakan:

$\varnothing . \mathrm{Mn}_{1}=\varnothing \times$ As terpasang $\mathrm{x}$ fy $\mathrm{x} \mathrm{jd}$ baru $=0,8.840,572 \cdot 400.394 .33823$

$=106,071 \mathrm{kNm}$

$\varnothing . \mathrm{Mn}_{2}=\varnothing$. As terpasang $\mathrm{x}$ fy $\mathrm{x} \mathrm{jd}$ baru $=0,8.402,286.400 .394 .33823$

$=50,764 \mathrm{kNm}$

$\mathrm{Mr} \quad=\varnothing \cdot \mathrm{Mn}_{1}+\varnothing \cdot \mathrm{Mn}_{2}$

$=106,071+50,764$

$=156,835 \mathrm{kNm}$

$\mathrm{Mr}>\mathrm{Mu}_{1}+\mathrm{Mu}_{2}$

$156,835 \mathrm{kNm}>117,9821 \mathrm{kNm}$ (aman)

Kontrol kuat momen tulangan lapangan $\varnothing$ Momen rencana $\geq$ Momen ultimate

$\varnothing . \mathrm{Mn}=\varnothing \times$ As perlu baru $\mathrm{x}$ fy $\mathrm{x} \mathrm{jd}$ baru $=0,8 \times 916,826 \times 400 \times 401,452$

$=117,77 \mathrm{kNm}>\mathrm{Mu}=95,696 \mathrm{kNm}$ 
Jadi tulangan yang digunakan 5 D16 mm, di bagian atas balok $2 \mathrm{D} 16 \mathrm{~mm}$, dan di bagian bawah balok $3 \mathrm{D} 16 \mathrm{~mm}$.

$\mathrm{Mu}_{1}=42,1349 \mathrm{kNm}$

$\mathrm{Mu}_{2}=84,2698 \mathrm{kNm}$

As terpasang atas $=\mathrm{n} \times$ Luas tulangan $=2.201 .143=402,286 \mathrm{~mm}$

As terpasang bawah $=\mathrm{n} \times$ Luas tulangan $=3.201 .143=603,429 \mathrm{~mm}$

Dari data mengenai tulangan yang digunakan, diperlukan cek kuat tulangan yang digunakan:

$\varnothing . \mathrm{Mn}_{1}=\varnothing \times$ As terpasang $\mathrm{x}$ fy $\mathrm{x}$ jd baru $=0,8.402,286.400 .401 .452$

$=51,679 \mathrm{kNm}$

$\varnothing . \mathrm{Mn}_{2}=\varnothing$. As terpasang $\mathrm{x}$ fy $\mathrm{x} \mathrm{jd}$ baru $=0,8.603,429.400 .401 .452$

$$
=77,519 \mathrm{kNm}
$$

$\mathrm{Mr} \quad=\varnothing \cdot \mathrm{Mn}_{1}+\varnothing \cdot \mathrm{Mn}_{2}$

$=71,067+106,599$

$=177,666 \mathrm{kNm}$

$\mathrm{Mr}>\mathrm{Mu}_{1}+\mathrm{Mu}_{2}$

$129,216 \mathrm{kNm}>95,6961 \mathrm{kNm}$ (aman)

Mengecek kondisi tulangan

$\rho$ terpasang $\leq \rho \max$

$\rho \mathrm{b}=\frac{0,85 . f c . \beta 1}{f y} \cdot \frac{600}{(600+f y)}=0.02709$

$\rho \max =0,75 \times \rho b=0.02032$

Cek tulangan max

Balok induk arah "Y"

$\rho=\frac{\text { As perlu }}{b \times d}=\frac{916,826}{300 \times 432}$

$=0.00707>\rho \max =0,02032$

Karena dengan tulangan sebanyak 6 D16 mm, nilai $\rho$ kurang dari $\rho \max$ maka tulangan sebanyak 6 D16 mm aman.

\section{e) PENULANGAN KOLOM}

Tulangan kolom yang digunakan adalah baja tulangan ulir (deform) dengan mutu fy $=400$ Mpa untuk $\mathrm{D} \geq 10 \mathrm{~mm}$ dan mutu beton $\mathrm{fc}=25$ Mpa.

1. Penulangan kolom

Data-data yang diperlukan untuk perencanaan penulangan kolom ini adalah:

Dimensi kolom $1=0,55 \mathrm{~m} \times 0,55 \mathrm{~m}$

Dimensi kolom $2=0,55 \mathrm{~m}$ x 0,55 m

Tinggi kolom bawah $=3,5 \mathrm{~m}$

Tinggi kolom atas $=3,5 \mathrm{~m}$

Dimensi balok kanan $=0,6 \mathrm{~m} \times 0,3 \mathrm{~m}$

Dimensi balok kiri $=0,6 \mathrm{~m} \times 0,3 \mathrm{~m}$

Panjang balok kanan $=7,073 \mathrm{~m}$

Panjang balok kiri $=7,073 \mathrm{~m}$

Dimensi tulangan $(\mathrm{D})=\mathrm{D} 16 \mathrm{~mm}$

Dimensi sengkang $(\mathrm{s}) \quad=\mathrm{D} 10 \mathrm{~mm}$
Selimut beton $(\mathrm{sb}) \quad=50 \mathrm{~mm}$

$\mathrm{d}=\mathrm{h}-\mathrm{sb}-\mathrm{D} / 2=550-50-8$

$=492 \mathrm{~mm}$

2. Beban-beban rencana:

Gaya aksial $(\mathrm{Pu})$ kolom bawah

$\mathrm{Pu}=2220,382 \mathrm{kN}=2220382 \mathrm{~N}$

Gaya aksial $(\mathrm{Pu})$ kolom atas

$\mathrm{Pu}=998,986 \mathrm{kN}=998,986 \mathrm{~N}$

Gaya aksial $(\mathrm{Pu})$ balok kanan

$\mathrm{Pu}=0,210 \mathrm{kN}$ (akibat beban mati)

$\mathrm{Pu}=0,164 \mathrm{kN}$ (akibat kombinasi 2)

Gaya aksial $(\mathrm{Pu})$ balok kiri

$\mathrm{Pu}=1,715 \mathrm{kN}$ (akibat beban mati)

$\mathrm{Pu}=2,112 \mathrm{kN}$ (akibat kombinasi 2)

Momen terkecil pada ujung kolom yang akan ditinjau,

$\mathrm{Mu}=41,2297 \mathrm{kNm}=41229700 \mathrm{Nmm}$

Momen terbesar pada ujung kolom yang akan ditinjau,

$\mathrm{Mu}=92,1994 \mathrm{kNm}=92199400 \mathrm{Nmm}$

3. Analisa struktur kolom

Kolom bawah

$\mathrm{Ig}=1 / 12 \cdot \mathrm{b} \cdot \mathrm{h}^{3}=\frac{1}{12} \times 550 \times 550^{3}$
$=7625520833 \mathrm{~mm}^{4}$

$\mathrm{Ec}=23500 \mathrm{Mpa}$

' $\beta=0,802$

$\mathrm{EI}=\frac{\frac{E c . I g}{2,5}}{1+\beta}=\frac{\frac{23500.7625520833}{2,5}}{1+0,802}=3,977796661$.

$10^{13} \mathrm{Nmm}^{2}$

Kolom atas

$\mathrm{Ig}=1 / 12 \cdot \mathrm{b} \cdot \mathrm{h}^{3}=\frac{1}{12} \times 550 \times 550^{3}$

$=7625520833 \mathrm{~mm}^{4}$

$\mathrm{Ec}=23500 \mathrm{Mpa}$

' $\beta=0,809$

$\mathrm{EI}=\frac{\frac{E c . I g}{2,5}}{1+\beta}=\frac{\frac{23500.7625520833}{2,5}}{1+0,809}$

$=3,962404413 \cdot 10^{13} \mathrm{Nmm}^{2}$

\section{Balok kanan}

$\operatorname{Ig}=1 / 12 \cdot b \cdot h^{3}=\frac{1}{12} \times 300 \times 600^{3}$

$=5400000000 \mathrm{~mm}^{4}$

$\mathrm{Ec}=23500 \mathrm{Mpa}$

' $\beta=1,536$

$\mathrm{EI}=\frac{\frac{E c . I g}{2,5}}{1+\beta}=\frac{\frac{23500.5400000000}{2,5}}{1+1,536}$

$=2,001577287 \cdot 10^{13} \mathrm{Nmm}^{2}$

Balok kiri

$\operatorname{Ig}=1 / 12 \cdot b \cdot h^{3}=\frac{1}{12} \times 300 \times 600^{3}$

$=5400000000 \mathrm{~mm}^{4}$ 
$\mathrm{Ec}=23500 \mathrm{Mpa}$

' $\beta=0,974$

$\mathrm{EI}=\frac{\frac{E c . I g}{2,5}}{1+\beta}=\frac{\frac{23500.5400000000}{2,5}}{1+0,974}$

$=2,571428571 \cdot 10^{13} \mathrm{Nmm}^{2}$

Faktor kekangan ujung pada kolom, struktur merupakan kolom yang dapat bergoyang (SNI 03-2847-2002 12.11 pasal 6). Struktur kolom termasuk dalam struktur portal bergoyang, karena ukuran portal dan beban-beban yang diterima oleh struktur tidak simetris. Hal ini menyebabkan faktor kekangan pada ujung atas kolom harus dicari terlebih dahulu.

$\Psi_{\mathrm{A}}=\frac{\frac{3,977796661 \cdot 10^{13}}{3500}+\frac{3,962404413 \cdot 10^{13}}{3500}}{\frac{2,001577287 \cdot 10^{13}}{7073}+\frac{2,571428571 \cdot 10^{13}}{7073}}$
$=3,508$

$\Psi_{\mathrm{B}}=0$, karena struktur kolom dengan perletakan jepit-jepit

Dari nomogram diperoleh faktor panjang efektif kolom, $\mathrm{k}=1,4$

a. Menentukan angka kelangsingan kolom $\mathrm{R}=0,3 \mathrm{~h}$ (0,3 untuk kolom persegi)

$$
\begin{aligned}
& =0,3 \times 550 \\
& =165
\end{aligned}
$$

$\left(\frac{k . l u}{r}\right)=\left(\frac{1,08 \times(4500-400)}{225}\right)<34-12 \cdot \frac{M 1}{M 2}$

$=27,151<34-12 \frac{41,2297}{92,1994}$

$=27,151<28,633$

Dari nilai perbandingan tersebut, dapat disimpulkan bahwa kolom yang ditinjau termasuk kolom pendek.

b. Menentukan eksentrisitas kolom

$$
\begin{aligned}
\mathrm{e} \quad & =\frac{M u}{P u} \\
= & \frac{92,1994}{2220,382} \\
& =41,52 \mathrm{~mm} \\
\mathrm{e} \min & =0,1 . \mathrm{h} \\
& =0,1.550 \\
& =55 \mathrm{~mm}
\end{aligned}
$$

c. Menghitung Pn perlu

$$
\begin{aligned}
\mathrm{Ag} \quad= & \mathrm{b} \times \mathrm{h} \\
& =550 \times 550 \\
& =302500 \mathrm{~mm}^{2}
\end{aligned}
$$

0,1.Ag.fc $\quad=0,1.302500 .25$

$$
=756,250 \mathrm{kN}<\mathrm{Pu}=2220,382 \mathrm{kN}
$$

Digunakan faktor reduksi 0,65, maka didapatkan:

$$
\begin{aligned}
\text { Pn perlu } & =\frac{2220,382}{0,65} \\
& =3415,972 \mathrm{kN}
\end{aligned}
$$

$$
\begin{array}{ll}
\text { a } & =\frac{\text { Pn Perlu }}{0,85 . f c . b} \\
& =\frac{3415,972}{0,85.25 .550} \\
& =292,275 \mathrm{~mm} \\
\text { As } & =\frac{\text { Pn perlu } .\left(e-\frac{b}{2}+\frac{a}{2}\right)}{f y \cdot(d-d \prime)} \\
& =\frac{3415,972\left(55-\frac{550}{2}+\frac{292,275}{2}\right)}{400(492-68)} \\
& =1487,69 \mathrm{~mm}^{2} \\
\text { As } & =\text { As }
\end{array}
$$

d. Kontrol luas tulangan

$$
\begin{aligned}
& \text { Ast }=\mathrm{As}+\mathrm{As} \text {, } \\
& 1487,69 \\
& =1487,69+ \\
& =2975,38 \mathrm{~mm}^{2} \\
& \text { As } \min \quad=1 \% \mathrm{Ag} \\
& =3025 \mathrm{~mm}^{2} \\
& =6 \% \mathrm{Ag} \\
& =18150 \mathrm{~mm}^{2}
\end{aligned}
$$

Nilai Ast $<$ As min, maka luas tulangan yang digunakan harus sama dengan atau lebih besar dari luasan tulangan minimum.

e. Pola keruntuhan tekan menggunakan pendekatan whitney

$$
\begin{gathered}
\text { An } \quad \text { Ag }+ \text { Ast } \\
=(550 \times 550)+3025 \\
=305525 \mathrm{~mm}^{2}
\end{gathered}
$$$$
=305525+0,85 \times 25+3025 \times 400
$$$$
=1515546,25 \mathrm{~N}
$$$$
=1515,546 \mathrm{kN}
$$

f. Kontrol keamanan kolom

$$
\begin{array}{ll}
\mathrm{Pu} & \geq 0,1 \cdot A g \cdot f \mathrm{c} \\
2220,382 \mathrm{kN} & \geq 0,1 \cdot(550 \mathrm{x} \\
550) .25 & \\
2220,382 \mathrm{kN} & \geq 756,250 \mathrm{kN} \\
\varnothing \mathrm{Pn} & =0,65 \times 3415,972 \\
& =2320,3818 \mathrm{kN}> \\
\mathrm{Pu}=2220,382 \mathrm{kN} & (\text { aman) }
\end{array}
$$




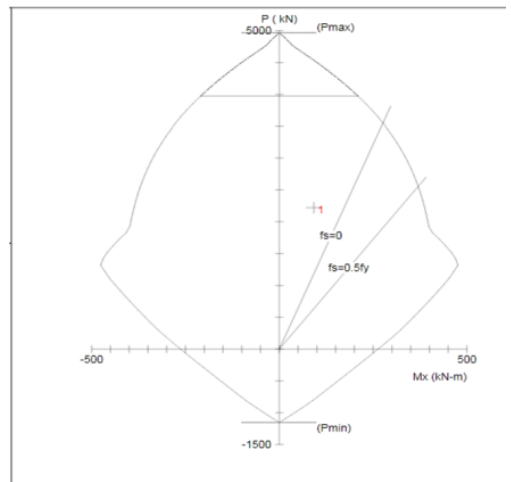

Gambar 4.9 Grafik rasio tulangan kolom

Dari diagram yang dihasilkan oleh Pca column, ini berdasarkan dari dimensi kolom, jumlah tulangan, mutu beton dan mutu baja yang digunakan bisa disimpulkan bahwa kolom yang direncanakan memiliki rasio aksial maksimum dan momen maksimum berada pada area grafik yang aman.

g. Tulangan pokok

$$
\begin{aligned}
\text { As perlu } & =1 \% \times \mathrm{b} \times \mathrm{h} \\
& =0,01.550 .550 \\
& =3025 \mathrm{~mm}^{2}
\end{aligned}
$$

Jumlah tulangan yang diperlukan adalah:

$$
\mathrm{n}=\frac{\text { As perlu }}{\text { Luas tulangan }}=\frac{3025}{201,143}=15,039
$$

Karena tulangan kolom dipasang pada keempat sisi, jadi tulangan yang digunakan adalah $16 \mathrm{D}$ $16 \mathrm{~mm}$.

$$
\begin{aligned}
& \text { h. Menghitung nilai } \varphi \text { Pn maksimum } \\
& \text { Luas tulangan yang digunakan (Ast) } \\
& \text { Ast }=\mathrm{n} \times \text { Luas tulangan } \\
& =16 \times 201,143 \\
& =3218,288 \mathrm{~mm}^{2} \\
& \text { Pn } \quad=0,80 \times\left(0,85 \times \mathrm{fc}^{\prime} \mathrm{x}(\mathrm{ag}-\mathrm{ast})+\mathrm{fy} \mathrm{x}\right. \\
& \text { ast })=0,8 \cdot(0,85.25 .(302500- \\
& 3218,288)+400.3218,288 \\
& =6375104,304 \mathrm{~N} \\
& =6375,104304 \mathrm{kN} \\
& \Phi \mathrm{Pn} \quad=0,85.6375,104304 \\
& =5418,838 \mathrm{kN}
\end{aligned}
$$

Dari hasil perhitungan dimensi dengan dibandingkan dengan perhitungan $\mathrm{Pu}$ terbesar, dengan syarat bahwa $\Phi \mathrm{Pn} \geq \mathrm{Pu}$

$\Phi P n=5418,838 \mathrm{kN} \geq \mathrm{Pu}$ terbesar $=2220,382$ $\mathrm{kN}$ (aman)

i. Tulangan sengkang kolom

Gaya geser perlu kolom (Vu,k)

$$
\begin{aligned}
\text { - } & \mathrm{Vu}, \mathrm{k}=\frac{M u 2-M u 1}{\lambda \mathrm{n}, \mathrm{k}} \\
= & \frac{92,1994-(-41,2297)}{3,5}
\end{aligned}
$$

$$
=38,1226 \mathrm{kN} \sim 38122,6 \mathrm{~N}
$$

- Gaya geser yang ditahan oleh beton (Vc)

$\mathrm{Vc} \quad=\left(1+\frac{P u, k}{14 \cdot A g}\right) \frac{\sqrt{f c^{\prime}}}{6} \cdot b \cdot d$

$=\left(1+\frac{2220382}{14.550 .550}\right) \frac{\sqrt{25}}{6} \cdot 550.492$

$=343728,1325 \mathrm{~N}$

- Gaya geser yang ditahan oleh sengkang (Vs) dan Vs maks

$$
\begin{aligned}
\mathrm{Vs} \quad & =\frac{V u-\phi \cdot V c}{\phi} \\
= & \frac{38122,6-0,75 \cdot 343728,1325}{0,75} \\
& =-292897,9992 \mathrm{~N} \\
\mathrm{Vs} \text { maks } & =\frac{2}{3} \cdot \sqrt{f c^{\prime}} \cdot b \cdot d \\
& =\frac{2}{3} \cdot \sqrt{25} \cdot 550.492 \\
& =902000 \mathrm{~N}
\end{aligned}
$$

Karena $\mathrm{Vs}<0$, maka dipakai tulangan sengkang mininal dengan luas per meter panjang seperti berikut:

- $\quad$ Luas tulangan sengkang perlu (Avu) untuk setiap panjang kolom

$$
\begin{aligned}
\mathrm{S}= & 1000 \mathrm{~mm} \\
\mathrm{Av}= & \frac{b . S}{f y .3} \\
& =\frac{550.1000}{400.3} \\
& =458,333 \mathrm{~mm}^{2} \\
\mathrm{Av}= & \frac{75 \sqrt{f c^{\prime}} \cdot b . S}{1200 . f y} \\
& =\frac{75 . \sqrt{25} .550 .1000}{1200.400} \\
& =429,6875 \mathrm{~mm}^{2}
\end{aligned}
$$

Dari kedua Av dipilih yang paling besar, yaitu $\mathrm{Avu}=458,333 \mathrm{~mm}^{2}$. Digunakan tulangan sengkang 2 kaki dengan $\mathrm{dp}=10 \mathrm{~mm}$ dengan jarang sengkang yaitu:

$$
\begin{aligned}
\mathrm{S} & =\frac{\frac{n}{4} \cdot \pi \cdot d p^{2} \cdot S}{A v \cdot u} \\
& =\frac{\frac{2}{4} \cdot 3,14 \cdot 10^{2} \cdot 1000}{458,333} \\
& =342,545 \mathrm{~mm}
\end{aligned}
$$

Kontrol jarak tulangan sengkang

$\mathrm{s} \leq 16 . \mathrm{D}=16.16=256 \mathrm{~mm}$

$\mathrm{s} \leq 48 . \mathrm{dp}=48.10=480 \mathrm{~mm}$

$\mathrm{s} \leq \mathrm{d} / 2=492 / 2=246 \mathrm{~mm}$

$\mathrm{s} \leq 600 \mathrm{~mm}$

dipakai nilai terkecil dan dibulatkan ke bawah yaitu:

$\mathrm{s}=250 \mathrm{~mm}<246 \mathrm{~mm}$

jadi digunakan tulangan sengkang D10 - 250 $\mathrm{mm}$.

\section{RAB}




\begin{tabular}{|c|c|r|}
\hline No & Uraian & \multicolumn{1}{|c|}{ Jumlah harga ( Rp ) } \\
\hline 1 & Pekerjaan Lantai 2 & $332,329,053.25$ \\
\hline 2 & Pekerjaan Lantai 3 & $616,142,538.17$ \\
\hline 3 & Pekerjaan Lantai 4 & $616,142,538.17$ \\
\hline 4 & Pekerjaan Lantai dak & $609,253,859.32$ \\
\hline \multicolumn{2}{|c|}{ Jumlah Total } & $2,173,867,988.90$ \\
\hline
\end{tabular}

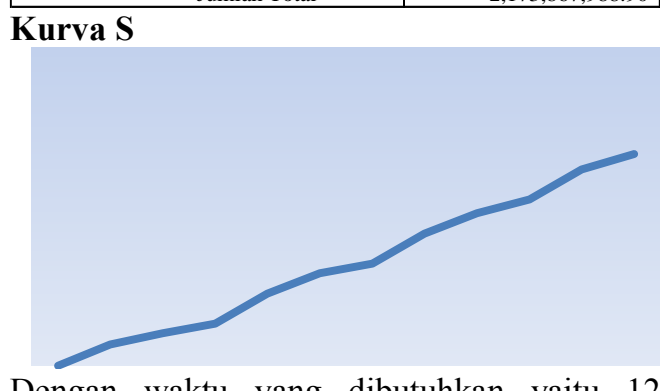

Dengan waktu yang dibutuhkan yaitu 12 minggu atau 3 bulan.

\section{Kesimpulan}

Berdasarkan analisis data dan analisis struktur yang dilakukan sebelumnya mulai dari analisis gambar kerja sampai analisis perhitungan pembebanan serta analisis struktur kontrol dimensioning, maka dapat ditarik kesimpulankesimpulan yang dapat diambil adalah:

1. Dari hasil permodelan struktur yang dilakukan oleh program SAP 2000 v.15 3D, gedung yang direncanakan masuk dalam katagori aman, hal ini terlihat jelas bahwa tidak ada struktur bangunan utama yang mengalami beban berlebihan (Ovestres) dalam arti struktur bangunan utama mampu menahan beban yang bekerja pada bangunan tersebut. Dengan hasil perhitungan sebagai berikut:

a. Kolom menggunakan dimensi $550 \mathrm{~mm}$ x $550 \mathrm{~mm}$ direncanakan $16 \mathrm{D} 16 \mathrm{~mm}$, pada desain awal digunakan dimensi $550 \mathrm{~mm} \times 550 \mathrm{~mm}$ dengan tulangan 20 D16 mm.

b. Balok induk arah " $\mathrm{X}$ " menggunakan dimensi $300 \mathrm{~mm}$ x $650 \mathrm{~mm}$ dengan menggunakan tulangan:

* Daerah tumpuan menggunakan tulangan $8 \mathrm{D} 16 \mathrm{~mm}$.

* Daerah lapangan menggunakan tulangan $8 \mathrm{D} 16 \mathrm{~mm}$.

sedangkan pada desain awal digunakan dengan jumlah tulangan tumpuan 12 D16 mm dan tulangan lapangan 11 D16 $\mathrm{mm}$.

c. Balok induk arah " $Y$ " menggunakan dimensi $300 \mathrm{~mm} \times 650 \mathrm{~mm}$ dengan menggunakan tulangan:

* Daerah tumpuan menggunakan tulangan 7 D16 mm.

* Daerahlapangan menggunakan tulangan $5 \mathrm{D} 16 \mathrm{~mm}$. sedangkan pada desain awal digunakan dengan jumlah tulangan tumpuan 10 D16 mm dan tulangan lapangan 8 D16 $\mathrm{mm}$.

d. Balok anak menggunakan dimensi 300 $\mathrm{mm} \times 500 \mathrm{~mm}$ dengan menggunakan tulangan:

* Daerah tumpuan menggunakan tulangan $6 \mathrm{D} 16 \mathrm{~mm}$.

* Daerah lapangan menggunakan tulangan 5 D16 mm.

sedangkan pada desain awal digunakan dengan jumlah tulangan tumpuan 8 D16 $\mathrm{mm}$ dan tulangan lapangan $7 \mathrm{D} 16 \mathrm{~mm}$.

e. Pada perhitungan perencanaan pelat dua arah yang telah dilakukan, diperoleh hasil tulangan :

- Pelat lantai

* Daerah lapangan arah $\mathrm{x}$ menggunakan tulangan D10 - 200 $\mathrm{mm}$

- Daerah tumpuan arah $\mathrm{x}$ menggunakan tulangan D10 - 200 $\mathrm{mm}$

* Daerah lapangan arah y menggunakan tulangan D10 - 100 $\mathrm{mm}$

- Daerah tumpuan arah y menggunakan tulangan D10 - 100 $\mathrm{mm}$.

- Pelat dak

* Daerah lapangan arah $\mathrm{x}$ menggunakan tulangan D10 - 200 $\mathrm{mm}$

* Daerah tumpuan arah $\mathrm{x}$ menggunakan tulangan D10 - 200 $\mathrm{mm}$

* Daerah lapangan arah y menggunakan tulangan D10 - 100 $\mathrm{mm}$

* Daerah tumpuan arah y menggunakan tulangan D10 - 100 $\mathrm{mm}$.

2. Total biaya yang dibutuhkan untuk membangun struktu atas sebesar Rp. 2.173.867.988.90

3. Total waktu yang dibutuhkan untuk membangun struktu atas yaitu selama 12 minggu atau 3 bulan.

\section{Saran}

Berdasarkan hasil dari pengerjaan tugas akhir ini memiliki beberapa saran untuk penulisan karya tulis berikutnya supaya didapatkan hasil penulisan tugas akhir yang lebih baik. 
1. Dibutuhkan literatur dan sumber referensi yang mendukung dalam penulisan tugas akhir ini supaya mempermudah sistem analisis yang dilakukan.

2. Menguasai aplikasi atau program hitungan yang digunakan untuk memperlancar proses pengerjaan.

3. Suatu struktur bangunan yang kokoh dan kuat memerlukan suatu perencanaan struktur yang baik dengan menggunakan peraturan- peraturan perencanaan secara tepat dan benar.

4. Mungkin tugas akhir ini masih jauh dari sempurna, namun penulis berusaha sebaik mungkin untuk mendekati benar, ada beberapa hal yang perlu diperhatikan untuk para penulis yang akan mengambil materi yang sama di waktu mendatang, yaitu seperti tinjauan struktur atas gedung rumah sakit juga bisa menjadi bahan pertimbangan.

\section{DAFTAR PUSTAKA}

Kusu, Gideon, Dasar-dasar Perencanaan Beton Bertulang, Penerbit Erlangga, Jakarta, 1993.

Imran, Iswandi, Perencanaan Struktur Gedung Beton Bertulang Tahan Gempa, Penerbit ITB, Bandung, 2010.

$$
\text { SNI 03-1726-2002. Tata Cara }
$$

Perencanaan Ketahanan Gempa Untuk Bangunan Gedung. Badan Standardisasi Nasional

SNI 03-1729-2002. Tata Cara Perencanaan Struktur Baja untuk Bangunan Gedung. Departemen Pekerjaan Umum

SNI 03-2847-2002. Tata Cara Perhitungan Struktur Beton untuk Bangunan Gedung. Badan Standardisasi Nasional

SNI 1727-1989. Tata Cara Perencanaan Pembebanan untuk Rumah dan Gedung. Badan Standardisasi Nasional

Asroni, A. 2010. Balok dan Pelat Beton Bertulang. Graha Ilmu. Yogyakarta.

Asroni Ali. 1998. Balok dan Pelat Beton Bertulang. Jakarta: Erlangga 